\title{
The response of tree squirrels to fragmentation: a review and synthesis
}

\author{
John L. Koprowski* \\ Wildlife Conservation and Management, School of Natural Resources, University of Arizona, Tucson, AZ 85721 USA \\ (Received 4 October 2004; accepted 7 March 2005)
}

\begin{abstract}
Habitat fragmentation is often considered a major threat to biodiversity; however, our understanding of how fragmentation impacts populations is poor. Identifying appropriate models for such studies is difficult. Tree squirrels are dependent on mature forests for food, cover and nests; these are habitats that are being fragmented rapidly and that are easily defined by humans. Squirrels represent excellent models for study of fragmentation. The literature on tree squirrels was reviewed to glean data on density and home-range size in forest fragments. Sufficient data were available on four species (Sciurus carolinensis, S. niger, S. vulgaris, Tamiasciurus hudsonicus). Density was negatively related to fragment size for $S$. carolinensis and $S$. niger and marginally so for T. hudsonicus. Sciurus vulgaris did not exhibit this relationship. Home-range size was analysed for three species of Sciurus and was positively related to forest fragment size for $S$. carolinensis and $S$. niger. Again, only S. vulgaris did not to show this relationship. Sciurus vulgaris is rarely found in small forest fragments and is believed to be especially sensitive to fragmentation; other tree squirrels appear to be sensitive to fragmentation in more subtle ways. Home range compaction provides a mechanism by which densities may increase in small fragments. The demographic consequences resultant from the high densities of squirrels found in small woodlots are not known but may explain the forest damage, avian nest predation and reduced diversity often cited to occur in woodland fragments.
\end{abstract}

\section{INTRODUCTION}

Habitat fragmentation is often considered one of the greatest threats to conservation of biodiversity and is a principal cause of endangerment (Czech \& Krausman, 1997; Lawler et al., 2002; Kerr \& Chilar, 2004). Consequences of fragmentation for abiotic and biotic components of ecosystems are varied (for reviews, see Yahner, 1988; Tscharntke et al., 2002). Most major ecosystems have been fragmented through anthropogenic activities in the last 200 years; however, forested ecosystems have undergone excessively high levels of fragmentation (Nixon, Havera \& Hansen, 1978; Middleton \& Merriam, 1983; Harris, 1984; Nixon \& Hansen, 1987; Sheperd \& Swihart, 1995; Verbeylen, De Bruyn \& Matthysen, 2003). Genetic variation is often, but not always, lost with habitat fragmentation (Avise, Neigel \& Arnold, 1984; Wauters et al., 1994b; Frankham, 1997; Eldridge et al., 1999; Small, Stone \& Cook, 2003). Biodiversity can also be lost (Laurance, 1990; Andren, 1994; Nupp \& Swihart, 1996; Lomolino \& Perault, 2000, 2001; McShea et al., 2003) as some species are unable to persist in small fragments; however, the response of

*E-mail: squirrel@ag.arizona.edu natural populations to fragments of different sizes is not well known.

In a meta-analysis of density and area relationships, Conner, Courtney \& Yoder (2000) found that for many taxa, densities are positively correlated with island size; however, mammals did not show this relationship. The sign of the relationship between density and patch size is often quite variable between studies and taxa (Bowers \& Matter, 1997; Bender, Contreras \& Fahrig, 1998; Debinski \& Holt, 2000; Krauss, Steffan-Dewenter \& Tscharntke, 2003). Island biogeographical models relate species diversity to population level processes and attributes such as dispersal and local extinction (Bowman, Cappuccino \& Fahrig, 2002), which suggests that demography might differ on the basis of site characteristics. Island populations of small mammals differ from mainland populations in a number of demographic parameters (for a review, see Gliwicz, 1980; Adler \& Levins, 1994). Densities of small mammals tend to be higher (Jewell, 1966; Sullivan, 1977; Tamarin, 1977; Bujalska, 1985) and more stable (Sullivan, 1977; Tamarin, 1977; Bujalska, 1985) on islands. Reproductive output is typically lower in island populations due to reduced litter size and/or increased age of first reproduction (Tamarin, 1978; Bujalska, 1985; Stamps \& Buechner, 1985). Survival is also often higher in island versus mainland 
populations (Tamarin, 1977; Adler \& Levins, 1994). Collectively the differences between island and mainland populations have been termed the 'island population syndrome' (Adler \& Levins, 1994). Whether islands of habitat have demographic characteristics similar to oceanic islands is not well known. Given that demographic parameters are important to our understanding of the response of organisms to fragmentation (Krohne, 1997), knowledge of how species respond to fragments of different size is required.

Tree squirrels (Sciurus and Tamiasciurus) may provide excellent models to assess the potential consequences of habitat fragmentation. Tree squirrels are obligates of mature forests (Gurnell, 1987; Steele \& Koprowski, 2001) that depend heavily on mature trees for nests (Baumgartner, 1939; Wauters \& Dhondt, 1990; Halloran \& Bekoff, 1994; Young, Greer \& Six, 2002) and food (Thompson \& Thompson, 1980; Korschgen, 1981; Gurnell, 1987; Koprowski, 1991, 1994a, 1994b; Koprowski \& Corse, 2001; Steele \& Koprowski, 2001). As a result, habitat fragments are relatively easily defined by humans at a scale that is probably meaningful to the organism. Furthermore, large leaf nests (Bouffard \& Hein, 1978; Don, 1981), body size (Gurnell, 1987; Steele \& Koprowski, 2001), diurnal activity (Hicks, 1949; Horwich, 1972; Thompson, 1977; Wauters, Swinnen \& Dhondt, 1992), moderate home-range sizes (Koprowski, 1998) and relative ease of trapping (Gurnell \& Pepper, 1994) make tree squirrels conspicuous for the estimation of density, assessment of home-range size and determination of presence/absence in a forest fragment. Due in large part to these characteristics, several species of tree squirrel have been studied frequently enough in a diversity of habitat patches that a data set of sufficient size exists to enable comparative studies. Finally, most tree squirrels are of precarious conservation status in at least some portion of their range (Koprowski \& Steele, 1998) with eight out of nine species of holarctic Sciurus and two out of three species of Tamiasciurus receiving some form of legal protection. Assessing the impacts of forest fragmentation on this group is thus quite timely. Previous studies of individual species in a local area have suggested that home-range size or density may be related to woodlot size (fox squirrels, Sciurus niger: Baumgartner, 1943; Sheperd \& Swihart, 1995; eastern grey squirrels, S. carolinensis: Erossy, 1973; Don, 1983; Fisher \& Merriam, 2000; red squirrels, Tamiasciurus hudsonicus: Bayne \& Hobson, 2000). Herein, a comparative generalised individuals-area relationship (Gaston \& Matter, 2002) approach will be used across species and geographical areas to assess the response of tree squirrel density and home-range size to forest fragmentation.

\section{METHODS}

Data were gleaned from published literature, theses and dissertations on red squirrels, fox squirrels, eastern grey squirrels and Eurasian red squirrel (S. vulgaris: common names after Wilson \& Cole, 2000). To be included, a value was required to meet the following criteria:

(1) Area of the woodlot or forest in which study occurred must be clearly defined. Often study area was welldefined, however, size of forest patch in which the study area was placed was not described by the authors.

(2) Forest fragment could not be described as the result of recent felling of trees.

(3) Home ranges were determined from radiotelemetry, observations, or extensive live trapping and represented $95 \%$ or $100 \%$ minimum convex polygon (MCP) estimates.

(4) Sex-specific home ranges must be provided.

(5) Densities of squirrels were determined from extensive live trapping efforts.

Study sites are only represented once in each of the analyses. Forests $>1000$ ha were assigned a value of 1000 ha, the largest fragment size considered in the analyses. Because Tamiasciurus hudsonicus defend territories throughout most of their range (Smith, 1968; Gurnell, 1987; Steele, 1998), while the species of Sciurus are home-range species, space-use data were only analysed for Sciurus. A meta-analysis could not be conducted due to the lack of appropriate detail to determine effect sizes in subsets of the sources.

\section{RESULTS}

The density of the four most commonly researched tree squirrels (Sciurus carolinensis, $n=10 ; S$. niger, $n=14 ;$ S. vulgaris, $n=22$; Tamiasciurus hudsonicus, $n=10$ ) is negatively related to woodlot size; the tendency for density to increase in small fragments is strong when data for all species are combined $\left(F_{1,55}=38.70, P<0.0001, R^{2}=0.468\right)$. To be certain that data from large continuous forests were not significantly changing the relationship, all data for forests $\geq 1000$ ha were removed and density:woodlot size was re-analysed; the relationship remained strongly negative $\left(F_{1,41}=18.06\right.$, $\left.P<0.001, R^{2}=0.311\right)$. When density and woodlot area data were analysed for species individually (Fig. 1), a strong negative relationship was detected for $S$. carolinensis $\left(F_{1,9}=70.38, P<0.0001, R^{2}=0.898\right)$ and $S$. niger $\left(F_{1,13}=127.97, P<0.0001, R^{2}=0.914\right)$, a moderately negative relationship was found for T. hudsonicus $\left(F_{1,9}=3.21, P=0.111, R^{2}=0.286\right)$, and no relationship for $S$. vulgaris $\left(F_{1,21}=1.22, P=0.281\right.$, $\left.R^{2}=0.0525\right)$. Sciurus vulgaris was rarely found in small woodlots and appears to require continuous forests or high levels of food supplementation or habitat connectivity to persist in fragmentated environs (Celada et al., 1994; Magris \& Gurnell, 2002; Verbeylen et al., 2003).

Home-range sizes of all species (Sciurus carolinensis, $n=11 ; S$. niger, $n=9 ; S$. vulgaris, $n=12$ ) were positively related to woodlot size for both males $\left(F_{1,33}=37.90, \quad P<0.0001, \quad R^{2}=0.542\right)$ and females 


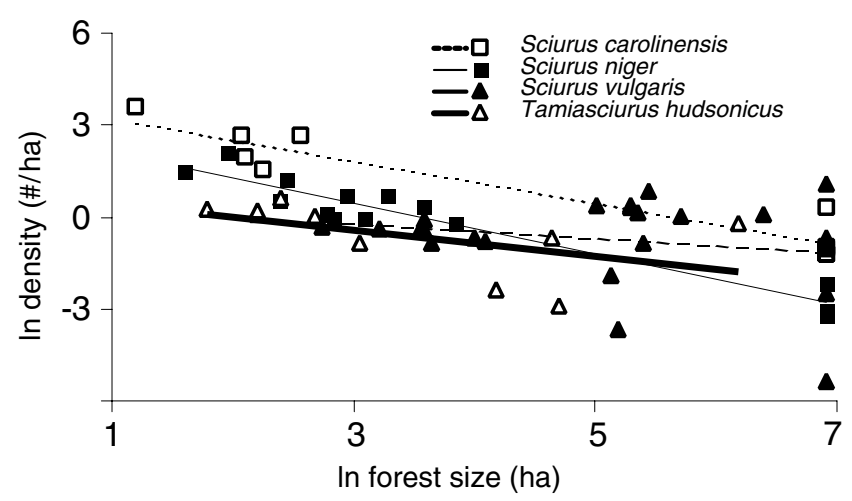

Fig. 1 Species-specific relationships between squirrel density and forest fragment size. Lines determined by simple linear regression. Data are from: Williams, 1936; Baumgartner, 1939, 1943; Moore, 1957; Flyger, 1960; Brink, 1964; Cordes, 1965; Taylor, 1966; Smith, 1967; Wood, 1967; Mosby, 1969; Barkalow, Hamilton \& Soots, 1970; Geeslin, 1970; Kemp \& Keith, 1970; Cordes \& Barkalow, 1972; Silva, 1972; Erossy, 1973; McCloskey, 1975; Adams, 1976; Whitehead, 1976; Fancy, 1981; Manski, Van Druff \& Flyger, 1981; Nixon, Havera \& Hansen, 1984; Herkert, 1985; Koprowski, 1985; Wauters \& Dhondt, 1985, 1992; Sullivan \& Moses, 1986; Weigl et al., 1989; Kantola \& Humphrey, 1990; Andren \& Delin, 1994; Wauters et al., 1994a,b, 2001; Shuttleworth, 1996; Halliwell, 1997; Münch, 1998; Delin \& Andren, 1999; Smith, 1999; Cagnin et al., 2000; Cartmel, 2000; Magris \& Gurnell, 2002.

$\left(F_{1,33}=36.43, \quad P<0.0001, R^{2}=0.532\right)$. Removal of woodlots $\geq 1000$ ha did not influence the relationship for either males $\left(F_{1,18}=18.64, P<0.0005, R^{2}=0.523\right)$ or females $\left(F_{1,18}=27.36, \quad P<0.0001, R^{2}=0.617\right)$. When species were examined independently (Fig. 2), a strong positive relationship between home-range size and woodlot area was noted for $S$. carolinensis males $\left(F_{1,8}=9.33, P<0.019, R^{2}=0.571\right)$ and females $\left(F_{1,8}=16.67, P<0.0047, R^{2}=0.704\right)$, for $S$. niger males $\left(F_{1,7}=52.76, P<0.0004, R^{2}=0.898\right)$ and females $\left(F_{1,7}=116.70, P<0.0001, R^{2}=0.951\right)$, but not for either male $\left(F_{1,11}=1.19, P=0.301, R^{2}=0.106\right)$ or female $\left(F_{1,11}=0.045, P=0.837, R^{2}=0.004\right) S$. vulgaris.

\section{DISCUSSION}

Densities and home-range dynamics of tree squirrels appear to be influenced by fragmentation. Gaston \& Matter (2002) suggest that the negative relationship between densities and areas can be an artifact of methods of estimation of density and area. This does not appear to be the case for tree squirrels. Compaction of home ranges, as typically determined from methods independent from trapping such as observation or radiotelemetry, appears to provide a mechanism for increases in density in small woodlots. The negative relationship between density and woodlot area appears to correspond to a positive relationship between home-range size and woodlot area.

Previous researchers have noted similar relationships in tree squirrels while working in local areas. Home
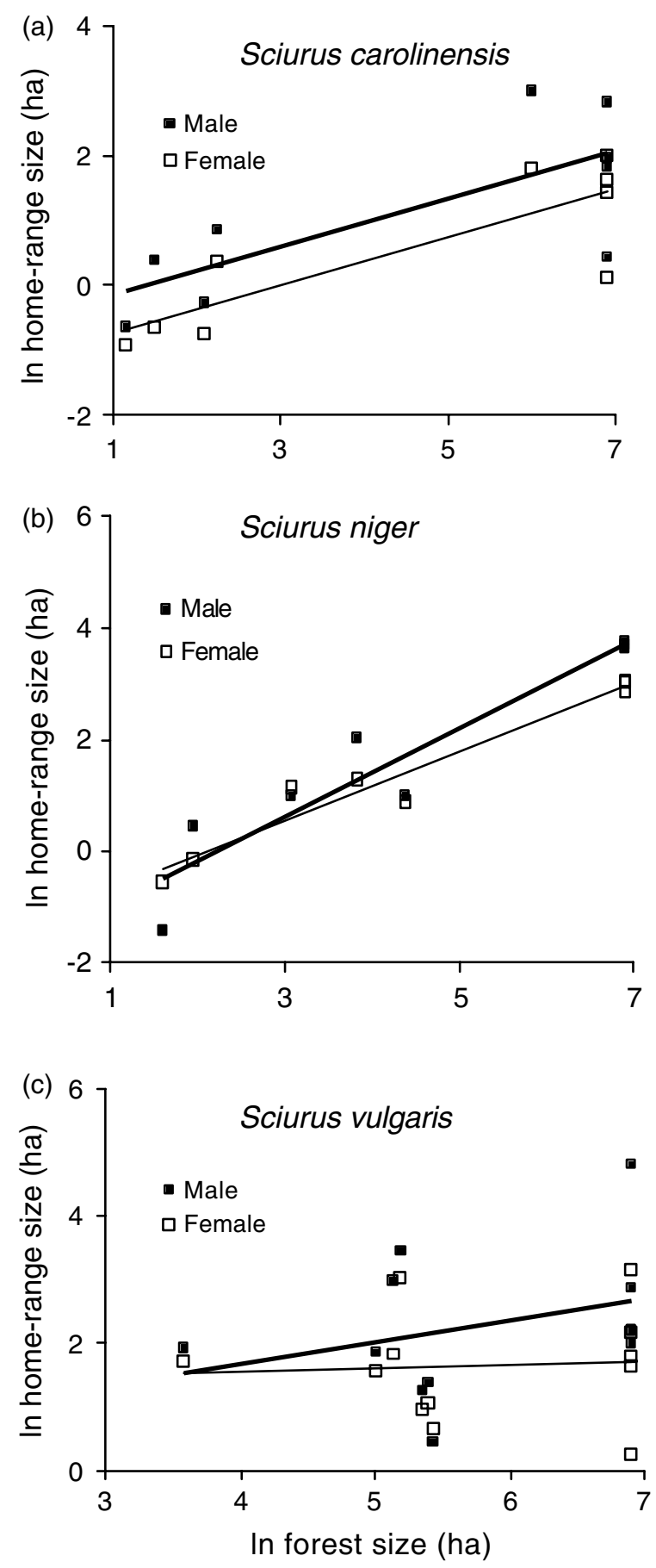

Fig. 2 Species-specific home-range size of male and female tree squirrels and forest fragment size. Lines determined by simple linear regression. (a) Sciurus carolinensis, (b) Sciurus niger, (c) Sciurus vulgaris. Data are from: Robinson \& McCowan, 1954; Flyger, 1960; Cordes, 1965; Taylor, 1966; Geeslin, 1970; Cordes \& Barkalow, 1972; Silva, 1972; Erossy, 1973; Doebel \& McGinnes, 1974; McCloskey, 1975; Adams, 1976; Benson, 1980; Wauters \& Dhondt, 1985, 1992; Weigl et al., 1989; Kantola \& Humphrey, 1990; Andren \& Delin, 1994; Wauters et al., 1994a, 2001; Sheperd \& Swihart, 1995; Shuttleworth, 1996; Halliwell, 1997; Münch, 1998; Smith, 1999; Cartmel, 2000; Conner, 2000; Nupp \& Swihart, 2000 .

ranges of fox squirrels (Baumgartner, 1943) and eastern grey squirrels (Erossy, 1973) were suggested to be 
positively related to woodlot size. Empirical support for this was found in fragmented forests in agricultural regions of Indiana (Sheperd \& Swihart, 1995). Densities were also noted to be higher in fragmented landscapes relative to continuous forests for red squirrels (Bayne \& Hobson, 2000) and eastern grey squirrels (Fisher \& Merriam, 2000). The strong negative relationship between density and woodlot size suggests upon extrapolation that extraordinarily large continuous forests would have densities of zero and forested areas approaching zero would have the highest squirrel densities. Clearly, a critical habitat patch size is required for persistence in tree squirrels and it appears that this size may vary between species (Fisher \& Merriam, 2000; Verbeylen et al., 2003).

How can higher densities of squirrels be maintained in isolated woodlots? Many mammalian predators are negatively impacted by fragmentation and use small fragments less frequently than large fragments (Virgos, Telleria \& Santos, 2002). Reduced predation pressure might enable higher densities of tree squirrels to accumulate within small fragments. High densities of squirrels in small woodlots might also suggest that areas with increased edge provide higher quality habitat than large continuous forests. Density can be a misleading indicator of habitat quality (Van Horne, 1983). Because woodlots included in this study were not the result of recent fragmentation events, densities were not likely to be in a transitory or non-equilibrium state. Although the relationship between density and area varies greatly between and among taxa, such a negative relationship has been reported for a variety of other mammal species (Nupp \& Swihart, 1996; Bowers \& Matter, 1997; Connor et al., 2000). Some ecosystems appear to subsidise higher population densities through increased productivity (Andersen \& Wait, 2001). Forest fragments may be able to 'subsidise' high densities of tree squirrels due to higher productivity, including increased tree growth (Murcia, 1995; Mourelle, Kellman \& Kwon, 2001; Asbjornsen, Vogt \& Ashton, 2004) and increased production of tree seeds (Johns, 1988; Herrera et al., 1994; Healy, 1997; Healy, Lewis \& Boose, 1999; Greene et al., 2002; Guariguata \& Saenz, 2002) at forest edges. Small fragments with high edge:area ratios may be more productive than large fragments, enabling densities to be maintained at higher levels, at least until other changes in community structure occur (Yahner, 1988; Murcia, 1995).

Why does Sciurus vulgaris not demonstrate the same response to fragmentation as other tree squirrels? First, data on Eurasian red squirrels in small fragments are sorely lacking, in part due to the continued decline of this species in many areas of their range in Europe (Wauters et al., 1994b; Verbeylen et al., 2003). Furthermore, Eurasian red squirrels typically are not found in isolated woodlots (Verboom \& van Apeldoorn, 1990; Celada et al., 1994). In some localities, home ranges of $S$. vulgaris are larger in small woodlots (Wauters, Casale \& Dhondt, 1994a) probably because individuals rely on numerous fragments in an archipelago of patches (Delin \& Andren, 1999; Verbeylen et al., 2003). Alternatively, on the Island of Jersey, Eurasian red squirrels are able to persist entirely within small to moderate woodlots with increased densities found in forest fragments where supplemental food is provided (Magris \& Gurnell, 2002). These studies suggest that Sciurus vulgaris may be able to persist in fragmented environments where patches are of high quality or where densities can be subsidised by the use of multiple fragments or supplemental food. Eurasian red squirrels appear to be particularly sensitive to forest fragmentation. Other species of tree squirrel were also sensitive to fragmentation but in apparently more subtle ways that demonstrated a modest level of area sensitivity permitting their persistence in smaller fragments than Eurasian red squirrels.

Eastern grey squirrels were introduced and spread throughout much of the range of Eurasian red squirrels in the United Kingdom (Gurnell, 1987). The spread of eastern grey squirrels has been attributed to a plethora of causes (Gurnell, 1987; Rushton et al., 1997; Gurnell et al., 2001; Lurz et al., 2001). Part of the success of the alien squirrels may be the ability to persist in a heavily fragmented landscape (Petit, Howard \& Stuart, 2004). Concern over the spread of eastern grey squirrels across continental Europe from introductions in Italy (Lurz et al., 2001; Bertolino \& Genovesi, 2003) is appropriate, especially given that the European continent is considered to have the most highly fragmented forests in the world (Wade et al., 2003). The few studies that report the persistence of Eurasian red squirrels in small fragments of forest were conducted in localities where alien eastern grey squirrels do not yet occur (Wauters et al., 1994a; Delin \& Andren, 1999; Magris \& Gurnell, 2002; Verbeylen et al., 2003). The present review of the literature suggests that eastern grey squirrels are found in much smaller fragments and in higher densities in small and moderate fragments than Eurasian red squirrels. As a result, habitat fragments probably serve as plentiful sources of eastern grey squirrels along colonising fronts. In addition, decreased sensitivity of eastern grey squirrels to fragmentation also suggests that habitat fragments could provide demographic and genetic rescue when populations of the alien are exterminated or lost (Tallmon, Luikart \& Waples, 2004). Efforts to maintain allotopy between these two species clearly are justified; however, this can create a conservation dilemma. Efforts to increase forested lands are underway and have lead to a $9 \%$ increase in woodlands but with only modest decreases in fragmentation (Petit, Howard \& Stuart, 2004). The ghosts of fragmentation past may be difficult to overcome.

Increases in density and compaction of home ranges in tree squirrels that occur with fragmentation suggest the potential for changes in social and mating systems. Density is frequently associated with changes in social organisation and space use (Lott, 1991; Travis, Slobodchikoff \& Keim, 1995; Kjellander et al., 2004). Increased interaction rates (Zenuto, Vassallo \& Busch, 2002), increased wounding (Boonstra \& Boag, 1992; Zenuto et al., 2002; Macdonald et al., 2004), increased weight loss (Macdonald et al., 2002) and reduced frequency or age of first reproduction (Wolff, Schauber \& 
Edge, 1997; Rodel et al., 2004) can occur in high density populations. In tree squirrels, home-range size is negatively related to density (Don, 1983) and communal nesting is frequent in small urban woodlots (Taylor, 1969; Koprowski, 1996). The propensity of female eastern grey squirrels to remain in their natal areas to form overlapping generations of kin as well as to nest in large groups (Koprowski, 1996) may further explain the ability of the alien species to invade and displace the solitary native Eurasian red squirrels (Gurnell et al., 2001). Behavioural changes associated with fragmentation are suggested to be important (Yahner \& Mahan, 1997).

High densities and behavioural differences in response to fragmentation of habitat may have unforeseen and negative community-level consequences. Damage to trees, such as bark stripping and girdling, increases with increasing density of eastern grey squirrels in the United Kingdom (Kenward \& Parish, 1986). Sciurus and Tamiasciurus are known predators of avian eggs and nestlings (Gurnell, 1987; Steele, 1998; Koprowski, $1994 a, b)$. Higher levels of nest predation are often, but not always, reported in forest fragments (For reviews, see Robinson et al., 1995; Chalfoun, Thompson \& Ratnaswamy, 2002; Thompson et al., 2002). Although the high nest predation rates are often attributed to edge effects, numerous alternative hypotheses exist (for a review, see Lariviere, 2003). Increased nest predation due to tree squirrels is reported in forest fragments (Yahner, 1988; Bayne \& Hobson, 1997, 1998, 2000). Such unforeseen community-level consequences emphasise the potential cascade of effects that can occur due to habitat fragmentation.

Finally, the response of other species of tree squirrels to forest fragmentation is not known. Despite the fact that the status of 10 out of 12 species of holarctic Sciurus and Tamiasciurus is of conservation concern, it was only possible to glean enough data on four of these species to assess their sensitivity to fragmentation. Data on the response of species outside the holartic regions, such as in tropical forests where trends in fragmentation are on the increase (Wade et al., 2003), are not available. Although tree squirrels have been suggested as potential indicators of forest health (Steele \& Koprowski, 2001; Kremsater et al., 2003), ecological publications are available for only about $13 \%$ of known species (unpublished results). My findings suggest that response to habitat fragmentation may differ in important ways even among closely related species. The ramifications of this differential sensitivity are poorly known.

\section{ACKNOWLEDGEMENTS}

I thank Sadie Bertelsen and Peter Lurz for assistance in obtaining and collating references, especially those found in unpublished sources. Sadie Bertelsen's initial enthusiasm for delving into the unpublished literature made this comparative approach possible. The University of Arizona's Undergraduate Biology Research Program provided partial support for Sadie Bertelsen to assist with literature searches. Discussions with S. Bertelsen, A. Edelman, K. Munroe, B. Pasch, P. Lurz, S. Rushton, L. Wauters and D. Wood helped increase the quality of the manuscript. The comments of two anonymous reviewers were exceptionally helpful in the final formulation of the manuscript.

\section{REFERENCES}

Adams, C. E. (1976). Measurements and characteristics of fox squirrels, Sciurus niger rufiventer, home ranges. Amer. Midl. Nat. 95: 211-215.

Adler, G. H. \& Levins, R. (1994). The island syndrome in rodent populations. Q. Rev. Biol. 69: 473-490.

Andersen, W. B. \& Wait, A. (2001). Subsidized island biogeography hypothesis: another new twist on an old theory. Ecol. Lett. 4: 289291.

Andren, H. (1994). Effects of habitat fragmentation on birds and mammals in landscapes with different proportions of suitable habitat: a review. Oikos 71: 355-366.

Andren, H. \& Delin, A. (1994). Habitat selection in the Eurasian red squirrel Sciurus vulgaris, in relation to forest fragmentation. Oikos 70: $3-48$.

Asbjornsen, H., Vogt, K. A. \& Ashton, M. S. (2004). Synergistic responses of oak, pine and shrub seedlings to edge environments and drought in a fragmented tropical highland oak forest, Oaxaca, Mexico. Forest Ecol. Mgmt. 192: 313-334.

Avise, J. C., Neigel, J. E. \& Arnold, J. (1984). Demographic influences on mitochondrial DNA lineage survivorship in animal populations. J. Mol. Evol. 20: 99-105.

Barkalow, F. S., Jr, Hamilton, R. B. \& Soots, R. F. (1970). Vital statistics of an unexploited gray squirrel population. J. Wildl. Mgmt. 34: 489500.

Baumgartner, L. L. (1939). Fox squirrel dens. J. Mammal. 20: 456-465.

Baumgartner, L. L. (1943). Fox squirrels in Ohio. J. Wildl. Mgmt. 7: 193-202.

Bayne, E. M. \& Hobson, K. A. (1997). Comparing the effects of landscape fragmentation by forestry and agriculture on predation of artificial nests. Conserv. Biol. 11: 1418-1429.

Bayne, E. M. \& Hobson, K. A. (1998). The effects of habitat fragmentation by forestry and agriculture on the abundance of small mammals in the southern boreal mixwood forests. Can. J. Zool. 76: 62-69.

Bayne, E. M. \& Hobson, K. A. (2000). Relative use of contiguous and fragmented boreal forest by red squirrels (Tamiasciurus hudsonicus). Can. J. Zool. 78: 359-365.

Bender, D. J., Contreras, T. A. \& Fahrig, L. (1998). Habitat loss and population decline: a meta-analysis of the patch size effect. Ecology 79: $517-533$.

Benson, B. N. (1980). Dominance relationships, mating behaviour and scent marking in fox squirrels (Sciurus niger). Mammalia 44: 143160.

Bertolino, S. \& Genovesi, P. (2003). Spread and attempted eradication of the grey squirrel (Sciurus carolinensis) in Italy, and consequences for the red squirrel (Sciurus vulgaris) in Eurasia. Biol. Conserv. 109: 351-358.

Boonstra, R. \& Boag, P. T. (1992). Spring declines in Microtus pennsylvanicus and the role of steroid hormones. J. Anim. Ecol. 61: 339-352.

Bouffard, S. H. \& Hein, D. (1978). Census methods for eastern gray squirrels. J. Wildl. Mgmt. 42: 550-557.

Bowers, M. A. \& Matter, S. F. (1997). Landscape ecology of mammals: relationships between density and patch-size. J. Mammal. 78: 999 1013.

Bowman, J. N., Cappuccino, N. \& Fahrig, L. (2002). Patch size and population density: the effect of immigration behavior. Conserv. Ecol. 6: 9. Available at URL: http://www.consecol.org/vol6/iss1/art9. 
Brink, C. H. (1964). Spruce seed as a food of the squirrels Tamiasciurus hudsonicus and Glaucomys sabrinus in interior Alaska. MSc thesis: University of Alaska, Fairbanks.

Bujalska, G. (1985). Population dynamics of an island population of Clethrionomys glareolus (Schreber 1780). Ann. Zool. Fenn. 22: 2834.

Cagnin, M., Aloise, G., Fiore, F. \& Oriolo, V. (2000). Habitat use and population density of the red squirrel, Sciurus vulgaris meridionalis, in the Sila Grande mountain range (Calabria, Italy). Ital. J. Zool. 67: $81-87$.

Cartmel, S. (2000). Squirrel ecology in a conifer forest in North Wales. PhD thesis: Queen Mary and Westfield College, University of London, London.

Celada, C., Bogliani, G., Gariboldi, A. \& Maracci, A. (1994). Occupancy of isolated woodlots by the red squirrel Sciurus vulgaris. in Italy. Biol. Conserv. 69: 177-183.

Chalfoun, A. D., Thompson, F. R., III \& Ratnaswamy, M. J. (2002). Nest predators and fragmentation: a review and meta-analysis. Conserv. Biol. 16: 306-318.

Conner, L. M. (2000). Home range sizes of fox squirrels in southwest Georgia. Proc. Southeast. Assoc. Fish Wildl. Agencies 54: 400-406.

Connor, E. F., Courtney, A. C. \& Yoder, J. M. (2000). Individuals-area relationships: the relationship between animal population density and area. Ecology 81: 734-748.

Cordes, C. L. (1965). Home range and movements of the eastern gray squirrel, Sciurus carolinensis carolinensis Gmelin, in Wake County, North Carolina. MSc thesis: North Carolina State University, Raleigh.

Cordes, C. L. \& Barkalow, F. S., Jr. (1972). Home range and dispersal in North Carolina gray squirrel population. Proc. Southeast. Assoc. Fish Wildl. Comm. 26:124-135.

Czech, B. \& Krausman, P. R. (1997). Distribution and causation of species endangerment in the United States. Science 277: 1116-1117.

Debinski, D. M. \& Holt, R. D. (2000). A survey and overview of habitat fragmentation experiments. Conserv. Biol. 14: 342-355.

Delin, A. E. \& Andren, H. (1999). Effects of habitat fragmentation on Eurasian red squirrel (Sciurus vulgaris) in a forest landscape. Landscape Ecol. 14: 67-72.

Doebel, J. H. \& McGinnes, B. S. (1974). Home range and activity of a gray squirrel population. J. Wildl. Mgmt. 38: 860-867.

Don, B. A. C. (1983). Home range characteristics and correlates in tree squirrels. Mammal Rev. 12: 123-132.

Eldridge, M. D., King, B. J. M., Loupis, A. K., Spencer, P. B. S., Taylor, A. C., Pope, L.C. \& Hall, G. P. (1999). Unprecedented low levels of genetic variation and inbreeding depression in an island population of the black-footed rock wallaby. Conserv. Biol. 13: 531-541.

Erossy, P. J. (1973). Home range and social organization of a freeranging population of gray squirrels (Sciurus carolinensis). MSc thesis: Bowling Green State University, Bowling Green.

Fancy, S. G. (1981). Daily movements of red squirrels, Tamiasciurus hudsonicus. Can. Field Nat. 95: 348-350.

Fisher, J. T. \& Merriam, G. (2000). Resource patch array use by two squirrel species in an agricultural landscape. Landscape Ecol. 15 333-338.

Flyger, V. F. (1960). Movements and home ranges of the gray squirrel, Sciurus carolinensis, in two Maryland woodlots. Ecology 41: 365 369.

Frankham, R. (1997). Do island populations have less genetic variation than mainland populations? Heredity 78: 311-327.

Gaston, K. J. \& Matter, S. F. (2002). Individuals-area relationships: comment. Ecology 83: 288-293.

Geeslin, H. G., Jr. (1970). A radio-tracking study of home range, movement, and habitat use of the fox squirrel (Sciurus niger) in east Texas. MSc thesis: Texas A \& M University, College Station.

Gliwicz, J. (1980). Island populations of rodents: their organization and functioning. Biol. Rev. 55: 109-138.

Greene, D. F., Messier, C., Asselin, H. \& Fortin, M. J. (2002). The effect of light availability and basal area on cone production in Abies balsamea and Picea glauca. Can. J. Bot. 80: 370-377.
Guariguata, M. R. \& Saenz, G. P. (2002). Post-logging acorn production and oak regeneration in a tropical montane forest, Costa Rica. Forest Ecol. Mgmt. 167: 285-293.

Gurnell, J. (1987). The natural history of squirrels. New York: Facts on File.

Gurnell, J. \& Pepper, H. (1994). Red squirrel conservation field study methods. United Kingdom Forestry Commission Research Information Note 191. Edinburgh: Forestry Commission.

Gurnell, J., Wauters, L. A., Preatoni, D. \& Tosi, G. (2001). Spacing behavior, kinship, and population dynamics of grey squirrels in a newly colonized broadleaf woodland in Italy. Can. J. Zool. 79: 15331543.

Halliwell, E. C. (1997). The ecology of red squirrels in Scotland in relation to pine marten predation. $\mathrm{PhD}$ thesis: University of Aberdeen, Aberdeen.

Halloran, M. E. \& Bekoff, M. (1994). Nesting behavior of Abert squirrels (Sciurus aberti). Ethology 97: 236-248.

Harris, L. D. (1984). The fragmented forest. Chicago: University of Chicago Press

Healy, W. M. (1997). Thinning New England oak stands to enhance acorn production. North. J. Appl. For. 14: 152-156.

Healy, W. M., Lewis. A. M. \& Boose, E. F. (1999). Variation in red oak acorn production. Forest Ecol. Mgmt. 116: 1-11.

Herkert, J. R. (1985). Demography of hunted and non-hunted populations of the fox squirrel (Sciurus niger). MSc thesis: Illinois State University, Normal.

Herrera, C. M., Jordano, P., Lopezsoria, L. \& Amat, J. A. (1994). Recruitment of a mast-fruiting, bird-dispersed tree bridging frugivore activity and seedling establishment. Ecol. Monogr. 64: $315-344$

Hicks, E. A. (1949). Ecological factors affecting the activity of the western fox squirrel, Sciurus niger rufiventer (Geoffroy). Ecol. Monogr. 19: 287-302.

Horwich, R. H. (1972). The ontogeny of social behavior in the gray squirrel (Sciurus carolinensis). Adv. Ethol. 8: 1-103.

Jewell, P. A. (1966). Breeding season and recruitment in some British mammals confined on small islands. Sym. Zool. Soc. Lond. 15: 89116.

Johns, A. D. (1988). Effects of selective timber extraction on rain forest structure and composition and some consequences for frugivores and folivores. Biotropica 20: 31-37.

Kantola, A. T. \& Humphrey, S. R. (1990). Habitat use by Sherman's fox squirrel (Sciurus niger shermani) in Florida. J. Mammal. 71: 411-419.

Kemp, G. A. \& Keith, L. B. (1970). Dynamics and regulation of red squirrel (Tamiasciurus hudsonicus) populations. Ecology 51: 763 779 .

Kenward, R. E. \& Parish, T. (1986). Bark stripping by gray squirrels (Sciurus carolinensis). J. Zool. (Lond.) 210: 473-481.

Kerr, J. T. \& Cihlar, J. (2004). Patterns and causes of species endangerment in Canada. Ecol. Applic. 14: 743-753.

Kjellander, P., Hewison, A. J. M., Liberg, O., Angibault, J. M., Bideau, E. \& Cargnelutti, B. (2004). Experimental evidence for density dependence of home range size in roe deer (Capreolus capreolus L.): a comparison of two long-term studies. Oecologia 139: 478485 .

Koprowski, J. L. (1985). Fox squirrel population trends and regulation in a southern Illinois woodlot, 1968-1984. MA thesis: Southern Illinois University, Carbondale

Koprowski, J. L. (1991). Response of fox squirrels and gray squirrels to a late spring-early summer food shortage. J. Mammal. 72: 267 272

Koprowski, J. L. (1994a). Sciurus niger. Mamm. Spec. 479: 1-9.

Koprowski, J. L. (1994b). Sciurus carolinensis. Mamm. Spec. 480: 1-9.

Koprowski, J. L. (1996). Natal philopatry, communal nesting, and kinship in fox squirrels and eastern gray squirrels. J. Mammal. 77: 1006-1016.

Koprowski, J L. (1998). Conflict between the sexes: a review of social and mating systems of the tree squirrels. In Ecology and evolutionary 
biology of tree squirrels: 33-41. Steele, M. A., Merritt, J. F. \& Zegers, D. A. (Eds). Martinsville: Virginia Museum of Natural History.

Koprowski, J. L. \& Corse, M. C. (2001). Food habits of Chiricahua fox squirrels (Sciurus nayaritensis chiricahuae). Southwest. Nat. 46: 62-65.

Koprowski, J. L. \& Steele, M. A. (1998). Future directions: research on the ecology of tree squirrels. In Ecology and evolutionary biology of tree squirrels: 309-310. Steele, M. A., Merritt, J. F. \& Zegers, D. A. (Eds). Martinsville: Virginia Museum of Natural History.

Korschgen, L. J. (1981). Foods of fox and gray squirrels in Missouri. $J$. Wildl. Mgmt. 45: 260-266.

Krauss, J., Steffan-Dewenter, I. \& Tscharntke, T. (2003). How does landscape context contribute to effects of habitat fragmentation on diversity and population density of butterflies. J. Biogeogr. 30: 889900.

Kremsater, L., Bunnell, F., Huggard, D. \& Dunsworth, G. (2003). Indicators to assess biological diversity: Weyershaeuer's coastal British Columbia forest project. Forest. Chron. 79: 590-601.

Krohne, D. T. (1997). Dynamics of metapopulations of small mammals. J. Mammal. 78: 1014-1026.

Lariviere, S. (2003). Edge effects, predator movements, and the travellane paradox. Wildlife Soc. B. 31: 315-320.

Laurance, W. F. (1990). Comparative responses of five arboreal marsupials to tropical forest fragmentation. J. Mammal. 71: 641653.

Lawler, J. J., Campbell, S. P., Guerry, A. D., Kolozsvary, M. B., O'Connor, R. J. \& Seward, L. C. N. (2002). The scope and treatment of threats in endangered species recovery plans. Ecol. Applic. 12: 663-667.

Lomolino, M. V. \& Perault, D. R. (2000). Assembly and disassembly of mammal communities in a fragmented temperate rain forest. Ecology 81: $1517-1532$.

Lomolino, M. V. \& Perault, D. R. (2001). Island biogeography and landscape ecology of mammals inhabiting fragmented, temperate rain forests. Global Ecol. Biogeogr. 10: 113-132.

Lott, D. F. (1991). Intraspecific variation in the social systems of wild vertebrates. New York: University of Cambridge Press.

Lurz, P. W. W., Rushton, S. P., Wauters, L. A., Bertolino, S., Currado, I., Mazzoglio, P. \& Shirley, M. D. F. (2001). Predicting grey squirrel expansion in North Italy: a spatially explict modelling approach. Landscape Ecol. 16: 407-420.

Macdonald, D. W., Newman, C., Stewart, P. D., Domingo-Roura, X. \& Johnson, P. J. (2002) Density-dependent regulation of body mass and condition in badgers (Meles meles) from Wytham Woods. Ecology 83: 2056-2061.

Macdonald, D. W., Harmsen, B. J., Johnson, P. J. \& Newman, C. (2004). Increasing frequency of bite wounds with increasing population density in Eurasian badgers, Meles meles. Anim. Behav. 67: 745751.

Magris, L. \& Gurnell, J. 2002. Population ecology of the red squirrel (Sciurus vulgaris) in a fragmented woodland ecosystem on the Island of Jersey, Channel Islands. J. Zool. (Lond.) 256: 99-112.

Manski, D. A., Van Druff, L. W. \& Flyger, V. (1981). Activities of gray squirrels and people in a downtown Washington, D.C. park: management implications. T. N. Am. Wildl. Nat. Res. 46: 439-454.

McCloskey, R. J. (1975). Description and analysis of the behavior of the fox squirrel in Iowa. $\mathrm{PhD}$ thesis: Iowa State University, Ames.

McShea, W. J., Pagels, J., Orrock, J., Harper, E. \& Koy, K. (2003). Mesic deciduous forest as patches of small-mammal richness within an Appalachian Mountain forest. J. Mammal. 84: 627-643.

Middleton, J. \& Merriam. G. (1983). Distribution of woodland species in farmland woods. J. Appl. Ecol. 20: 625-644.

Moore, J. C. (1957). The natural history of the fox squirrel, Sciurus niger shermani. B. Am. Mus. Nat. Hist. 113: 1-71.

Mosby, H. S. (1969). The influence of hunting on the population dynamics of a woodlot gray squirrel population. J. Wildl. Mgmt. 33: $59-73$.
Mourelle, C., Kellman, M. \& Kwon, L. (2001). Light occlusion at forest edges: an analysis of tree architectural characteristics. Forest Ecol. Mgmt. 154: 179-192.

Münch, S. (1998). Populationsökologie, aktivität, raum- und habitatsnutzung beim Europäischen eichhörnchen (Sciurus vulgaris) im Bergmischwald des Nationalparks Bayerischer Wald. PhD thesis: Pharmazeutischen Fakultät der friedrich-Schiller Universität Jena, Jena.

Murcia, C. (1995). Edge effects in fragmented forests: implications for conservation. Trends Ecol. Evol. 10: 58-62.

Nixon, C. M. \& Hansen, L. P. (1987). Managing forests to maintain populations of gray and fox squirrels. Illinois Depart. Conserv. Tech. B. 5: $1-35$.

Nixon, C. M., Havera, S. P. \& Hansen, L. P. (1978). Distribution and abundance of the gray squirrel in Illinois. Biol. Notes Illinois Nat. Hist. Surv. 105: 1-55.

Nixon, C. M., Havera, S. P. \& Hansen, L. P. (1984). Effects of nest boxes on fox squirrel demography, condition and shelter use. Am. Midl. Nat. 112: 157-171.

Nupp, T. E. \& Swihart, R. K. (1996). Effect of forest patch area on population attributes of white-footed mice (Peromyscus leucopus) in fragmented landscapes. Can. J. Zool. 74: 467-472.

Nupp, T. E. \& Swihart, R. K. (2000). Landscape-level correlates of small mammal assemblages in forest fragments of farmland. J. Mammal. 81: $512-526$

Petit, S., Howard, D. C. \& Stuart, R. C. (2004). A national perspective on recent changes in the spatial characteristics of woodland in the British landscape. Landscape Urban Plan. 69: 127-135.

Robinson, D. J. \& McCowan, I. M. (1954). An introduced population of the gray squirrel (Sciurus carolinensis Gmelin) in British Columbia. Can. J. Zool. 32: 261-282.

Robinson, S. K., Thompson, F. R., III, Donovan, T. M., Whitehead, D. R. \& Faaborg, J. (1995). Regional forest fragmentation and the nesting success of migratory birds. Science 267: 1987-1990.

Rodel, H. G., Bora, A., Kaiser, J., Kaetzke, P., Khaschei, M. \& von Holst, D. (2004). Density-dependent reproduction in the European rabbit: a consequence of individual response and age-dependent reproductive performance. Oikos 104: 529-539.

Rushton, S. P., Lurz, P. W. W., Fuller, R. \& Garson, P. J. (1997). Modelling the distribution of the red and grey squirrel at the landscape scale: a combined GIS and population dynamics approach. J. Appl. Ecol. 34: 1137-1154.

Sheperd, B. F. \& Swihart, R. K. (1995). Spatial dynamics of fox squirrels (Sciurus niger) in fragmented landscapes. Can. J. Zool. 73: 20982105.

Shuttleworth, C. (1996). The effects of supplemental feeding on the red squirrel (Sciurus vulgaris). $\mathrm{PhD}$ thesis: Royal Holloway and Bedford College, University of London, London.

Silva, M. D. (1972). Home range and movement of fox squirrels in eastcentral Illinois. MSc thesis: Eastern Illinois University, Charleston.

Small, M. P., Stone, K. D. \& Cook, J. A. (2003). American marten (Martes americana) in the Pacific Northwest: population differentiation across a landscape fragmented in time and space. Mol. Ecol. 12: 89-103.

Smith, C. C. (1968). The adaptive nature of social organization in the genus of three squirrels Tamiasciurus. Ecol. Monogr. 38: 31-63.

Smith, D. F. E. (1999). Grey squirrel, Sciurus carolinensis, population dynamics and feeding biology in a conifer forest. $\mathrm{PhD}$ thesis: Queen Mary and Westfield College, University of London, London.

Smith, M. C. (1967). Red squirrel ecology (Tamiasciurus hudsonicus) during spruce cone failure in Alaska. MSc thesis: University of Alaska, Fairbanks.

Stamps, J. A. \& Buechner, M. (1985). The territorial defense hypothesis and the ecology of insular vertebrates. Q. Rev. Biol. 60: 155181.

Steele, M. A. (1998). Tamiasciurus hudsonicus. Mamm. Spec. 586: 1-8. Steele, M. A. \& Koprowski, J. L. (2001). North American tree squirrels. Washington: Smithsonian Institution Press. 
Sullivan T. P. (1977). Demography and dispersal in island and mainland populations of the deer mouse, Peromyscus maniculatus. Ecology 58: 964-978.

Sullivan, T. P. (1990). Responses of red squirrel (Tamiasciurus hudsonicus) populations to supplemental food. J. Mammal. 71: 579590.

Sullivan, T. P. \& Moses, R. A. (1986). Red squirrel populations in natural and managed stands of lodgepole pine. J. Wildl. Mgmt. 50: 595601.

Tallmon, D. A., Luikart, G. \& Waples, R. S. (2004). The alluring simplicity and complex reality of genetic rescue. Trends Ecol. Evol. 19: 489-496.

Tamarin, R. H. (1977). Demography of the beach vole (Microtus breweri) and the meadow vole (Microtus pennsylvanicus) in southeastern Massachusetts. Ecology 58:1310-1321.

Tamarin, R. H. (1978). Dispersal, population regulation, and K-selection in field mice. Am. Nat. 112: 545-555.

Taylor, J. C. (1966). Home range and agonistic behaviour in the grey squirrel. Sym. Zool. Soc. Lond. 18: 229-235.

Taylor, J. C. (1969). Social structure and behaviour in a grey squirrel population. PhD Thesis: University of London, London.

Thompson, D. C. (1977). Diurnal and seasonal activity of the grey squirrel (Sciurus carolinensis). Can. J. Zool. 55: 1185-1189.

Thompson, D. C. \& Thompson, P. S. (1980). Food habits and caching behavior of urban grey squirrels. Can. J. Zool. 58: 701-710.

Thompson, F.R., III, Donovan, T. M., DeGraaf, R. M., Faaborg, J. \& Robinson, S. K. (2002). A multi-scale perspective of the effects of forest fragmentation on birds in eastern forests. Stud. Avian Biol. 25 $8-9$.

Travis, S. E., Slobodchikoff, C. N. \& Keim, P. (1995). Ecological and demographic effects on intraspecific variation in the social system of prairie dogs. Ecology 76:1794-1803.

Tscharntke, T., Steffan-Dewenter, I., Kruess, A. \& Thies, C. (2002). Characteristics of insect populations on habitat fragments: a mini review. Ecol. Res. 17: 229-239.

Van Horne, B. (1983). Density as a misleading indicator of habitat quality. J. Wildl. Mgmt. 47: 893-901.

Verbeylen, G., De Bruyn, L. \& Matthysen, E. (2003). Patch occupancy, population density and dynamics in a fragmented red squirrel Sciurus vulgaris, population. Ecography 26: 118-128.

Verboom, B. \& van Apeldoorn, R. (1990). Effects of habitat fragmentation on the red squirrel, Sciurus vulgaris L. Landscape Ecol. 4: 171-176.

Virgos, E., Telleria, J. L. \& Santos, T. (2002). A comparison on the response to forest fragmentation by medium-sized Iberian carnivores in central Spain. Biodiv. Conserv. 11: 1063-1079.

Wade, T. G., Riitters, K. H., Wickham, J. D. \& Jones, K. B. (2003). Distribution and causes of global forest fragmentation. Conserv. Ecol. 7: 2 . Available online at URL: http://www.consecol.org/vol7/iss2/ art7.
Wauters, L. A. \& Dhondt, A. A. (1985). Population dynamics and social behaviour of red squirrel populations in different habitats. Congr. Int. Union Game Biol. 27: 311-318.

Wauters, L. A. \& Dhondt, A. A. (1990). Nest use by red squirrels (Sciurus vulgaris Linnaeus, 1758). Mammalia 54: 377-389.

Wauters, L. A. \& Dhondt, A. A. (1992). Spacing behavior of red squirrels, Sciurus vulgaris: variation between habitats and the sexes. Anim. Behav. 43: 297-311.

Wauters, L. A., Swinnen, C. \& Dhondt, A. A. (1992). Activity budget and foraging behavior of red squirrels (Sciurus vulgaris) in coniferous and deciduous habitats. J. Zool (Lond.) 227: 71-86.

Wauters, L. A., Casale, P. \& Dhondt, A. A. (1994a). Space use and dispersal of red squirrels in fragmented habitats. Oikos 69: 140-146.

Wauters, L. A., Hutchinson, Y., Parkin, D. T. \& Dhondt, A. A. (1994b). The effects of habitat fragmentation on demography and on the loss of genetic variation in the red squirrel. Proc. Roy. Soc. Lond. Ser. B Biol. Sci. 255: 107-111.

Wauters L. A., Gurnell, J., Preatoni, D. \& Tosi, G. (2001). Effects of spatial variation in food availability on spacing behaviour and demography of Eurasian red squirrels Ecography 24: 525-538.

Weigl, P. D., Steele, M. A., Sherman, L. J., Ha, J. C. \& Sharpe, T. L. (1989). The ecology of the fox squirrel (Sciurus niger) in North Carolina: implications for survival in the southeast. B Tall Timbers Res. Sta. 24: 1-93.

Whitehead, A. G. (1976). A population study of the gray squirrel with special reference to trapping success. MSc thesis: Tennessee Technological University, Cookeville.

Williams, A. B. (1936). The composition and dynamics of a beechmaple climax community. Ecol. Monogr. 6: 317-408.

Wilson, D. E. \& Cole, F. R. (2000). Common names of mammals of the world. Washington: Smithsonian Institution Press.

Wolff, J. O., Schauber, E. M. \& Edge, W. D. (1997). Effects of habitat loss and fragmentation on the behavior and demography of graytailed voles. Conserv. Biol. 11: 945-956.

Wood, T. J. (1967). Ecology and population dynamics of the red squirrel (Tamiasciurus hudsonicus) in Wood Buffalo National Park. MA thesis: University of Saskatchewan, Saskatoon

Yahner, R. H. (1988). Changes in wildlife communities near edges. Conserv. Biol. 2: 333-339.

Yahner, R. H. \& Mahan, C. G. (1997). Behavioral considerations in fragmented landscapes. Conserv. Biol. 11: 569-570.

Young, P. J., Greer, V. L. \& Six, S. K. (2002). Characteristics of bolus nests of red squirrels in the Pinaleño and White Mountains of Arizona. Southwest. Nat. 47: 267-275.

Zenuto, R. R., Vassallo, A. I. \& Busch, C. (2002). Social and reproductive behavior of the subterrean solitary rodent Ctenomys talarum (Rodentia: Ctenomyidae) in a semi-natural enclosure. Rev. Chilena Hist. Nat. 75: 165-177. 